\title{
Gonococcal ribosomes as skin test antigens I. Preliminary tests of sensitivity and specificity
}

W. L. KOOSTRA, R. C. JUDD, AND R. E. BAKER

From the Department of Microbiology and Stella Duncan Memorial Research Institute, University of Montana, Missoula, Montana 59801, U.S.A.

\section{Summary}

Ribosomes isolated from $N$. gonorrhoeae and $N$. meningitidis were used as skin test antigens in guinea-pigs which had been previously sensitized with killed Neisseria cells in incomplete Freund adjuvant. Intradermal injection of ribosomes from skin test dose $N$. gonorrhoeae into the skin of animals sensitized to the homologous organism was characterized by a specificity based upon ribosomal skin test dose 50's $\left(\mathrm{STD}_{50}\right)$ sensitivity which was at least five-fold greater than that of the animals sensitized to the heterologous organism. The sensitized guinea-pigs had lost their skin-test reactivity within 3 months of the cessation of immunization but regained it immediately on reimmunization.

The results of this model system indicate that gonococcal ribosomes may be used as antigens in skin testing or other testing modes in gonorrhoea.

\section{Introduction}

The epidemic proportions of gonorrhoea evoke an urgent need for a method of diagnosis which could be used in large-scale screening (Schmale, 1970; Lewin, 1973) to supplement or, perhaps, to supplant the current standard diagnostic procedure of stained smears and cultures. The problems of diagnosis are compounded by a reservoir of victims who are asymptomatic and therefore do not seek treatment (Handsfield and others, 1974).

Several serodiagnostic tests for gonorrhoea already employed with limited success have included complement-fixation, flocculation, microprecipitin, passive haemagglutination, and latex-agglutination methods using a variety of gonococcal antigens (Brit. med. F., 1972; Willcox, 1972). By contrast, relatively little effort has been applied to the cellmediated immune response of patients with gonorrhoea. From the 1920 s to the early 1940 s there were

Received for publication June 30, 1975 reports of infected persons in whom could be demonstrated cutaneous delayed hypersensitivity reactions to intradermal injections of gonococcal cells, cell fractions, or culture filtrates (Herrold, 1922; Kohler, 1931; Rossett, 1939; Casper, 1941; Corbus and Corbus, 1941). Unlike the numerous criticisms of serodiagnostic tests, all investigators using skin tests for diagnosis reported favourably upon its specificity. After a gap of nearly 30 years, a cellmediated response in patients with gonorrhoea has recently been demonstrated by Kraus and others (1970), Esquenazi and Streitfeld (1973), and Grimble and McIllmurray (1973) using the lymphocyte transformation test.

Bacterial ribosomes have been shown to possess immunogenicity and specificity (Sarker and Som, 1969) and to stimulate a delayed hypersensitivity response in skin testing of guinea-pigs sensitized with Mycobacteria (Youmans and Youmans, 1965; Baker, Hill, and Larson, 1973). These results suggested the possibility that gonococcal ribosomes might be reactive as skin test antigens in sensitized animals used as a model system of the human infection. This study was designed to determine the sensitivity and specificity of gonococcal ribosomes in eliciting a cellmediated delayed hypersensitivity response in guineapigs sensitized with killed Neisseria. In the following paper (Judd and Koostra, 1976: see p. 28), we further define the ribosomal skin test system and the use of the macrophage migration inhibition test as an in vitro correlate.

\section{Material and methods}

ANIMALS

Hartley strain guinea-pigs, male and female, weighing $300-500 \mathrm{~g}$. were purchased from a local source.

\section{BACTERIA}

These were clinical isolates including Neisseria gonorrhoeae, Neisseria meningitidis, Neisseria lactamicus, Neisseria flavescens, and a Moraxella species. Each bacterium was grown separately in Thayer-Martin medium without inhibitors (Thayer and Martin, 1966) for seven days at 
$37^{\circ} \mathrm{C}$ in static candle extinction jars. The organisms were in late log phase of growth at this time.

\section{SENSITIZATION OF GUINEA-PIGS}

Incomplete Freund adjuvant (IFA) was prepared by mixing ten parts of the appropriate killed whole cells in 1.5 M saline, nine parts of sterile mineral oil, and one part Arlacel A. The final concentration of antigen was $100 \mu \mathrm{g}$./ $0.1 \mathrm{ml}$. Animals were sensitized with the appropriate antigen by injecting $0.1 \mathrm{ml}$. IFA into each hind footpad (total dose, $200 \mu \mathrm{g}$. per guinea-pig). To monitor sensitization, the animals were skin tested every 7 days by intradermal injection of $0.1 \mathrm{ml}$. of a $200 \mu \mathrm{g} . / \mathrm{ml}$. preparation of whole cells in $1.5 \mathrm{M}$ saline. Sterile $1.5 \mathrm{M}$ saline was also injected as a control. Right-angle diameters and lesion thickness were measured at $24 \mathrm{hrs}$ after injection using a Kroplin Schnell tester, and skin lesion volumes calculated. IFA stimulation was repeated (once or at most twice) until a delayed hypersensitivity lesion with a volume of $15 \mathrm{~mm}^{3}$ or greater was observed. This volume was considered a positive skin test (Waksman and Matoltsy, 1958; Larson and others, 1966). The formula for lesion volume is:

$$
\text { Width } \times \text { Length } \times \frac{1}{2} \text { Height } \times \frac{3}{4}=\text { Volume }
$$

\section{PREPARATION OF CRUDE RIBOSOMES}

Ribosomes were extracted from 7-day cultures of $N$. Gonorrhoeae and $N$. meningitidis using methods described by Hill, Thompson, and Anderegg (1969). All preparations were kept below $5^{\circ} \mathrm{C}$ at all times.

\section{BUFFERS}

$70 S$ buffer- $0.01 \mathrm{M} \mathrm{MgCl}_{2} ; 0.01 \mathrm{M}$ Tris- $\mathrm{HCl}(\mathrm{pH} \mathrm{7.4)}$; $0.07 \mathrm{M} \mathrm{KCl}$-maintains bacterial ribosomes in $70 \mathrm{~S}$ configuration.

$50 S$ buffer- $0.001 \mathrm{M} \mathrm{MgCl}_{2} ; 0.01 \mathrm{M}$ Tris- $\mathrm{HCl}(\mathrm{pH}$ 7.4); $0.07 \mathrm{M} \mathrm{KCl}$-dissociates bacterial ribosomes into $50 \mathrm{~S}$ and $30 \mathrm{~S}$ subfractions.

65S (wash buffer- $0.01 \mathrm{M} \mathrm{MgCl}_{2} ; 0.01 \mathrm{M}$ Tris- $\mathrm{HCl}$ (pH 7.4); $0.5 \mathrm{M} \mathrm{NH}_{4} \mathrm{Cl}$-maintains $70 \mathrm{~S}$ configuration of bacterial ribosomes while effecting partial removal of adsorbed and nascent proteins.

A typical procedure for the isolation of ribosomes is as follows:

Approximately $15 \mathrm{~g}$. of a cell paste was washed twice in ten volumes of $70 \mathrm{~S}$ buffer and centrifuged at $12,000 \mathrm{G}$. for $10 \mathrm{~min}$. The pellet was re-suspended at a concentration of $175 \mathrm{mg} . / \mathrm{ml}$. wet weight in $70 \mathrm{~S}$ buffer. This slurry was then transferred to a pre-chilled Sorvall-Ribi Cell Fractionator and the cells were pressure-disrupted at 13,000 psi, with the temperature held between $5-10^{\circ} \mathrm{C}$.

Whole cells, cell walls, and cellular debris were removed from the disrupted preparation by two centrifugations at $20,000 \mathrm{G}$. for $30 \mathrm{~min}$. in a Sorvall $\mathrm{RC}-2 \mathrm{~B}$ refrigerated centrifuge. The supernatant was then centrifuged at $254,000 \mathrm{G}$. for $2.5 \mathrm{hrs}$ in a Type $60 \mathrm{Ti}$ rotor in a Beckman model L2-65B ultracentrifuge. The pellet was resuspended in $200 \mathrm{ml}$. wash buffer and stirred overnight at $4^{\circ} \mathrm{C}$. The preparation was again centrifuged at $20,000 \mathrm{G}$. for $30 \mathrm{~min}$. to remove particulate matter and then centrifuged at $254,000 \mathrm{G}$. for $2 \cdot 5 \mathrm{hrs}$ to re-pellet the ribosomes. The resultant pellet was re-suspended in a minimal amount of wash buffer (or $50 \mathrm{~S}$ buffer if the preparation was to be used for subunit isolation) and stored at $-80^{\circ} \mathrm{C}$. until needed.

\section{ISOLATION OF RIBOSOMAL SUBFRACTIONS}

Crude ribosomes as prepared above were stirred for $3 \mathrm{hrs}$ in $50 \mathrm{~S}$ buffer at $4^{\circ} \mathrm{C}$. This suspension was layered on a 10 to 30 per cent. continuous sucrose density gradient and centrifuged at $81,000 \mathrm{G}$. in an $\mathrm{SW}-27$ rotor for $8.5 \mathrm{hrs}$. The preparation was then collected by puncturing the bottom of the centrifuge tubes and collecting $1.0 \mathrm{ml}$. samples. The samples were analysed in a Gilford-modified Beckman DU spectrophotometer at 260 and $280 \mathrm{~nm}$. The $260 \mathrm{~nm}$ readings were plotted against volume and the samples under the $50 \mathrm{~S}$ and $30 \mathrm{~S}$ peaks were combined to form the $50 \mathrm{~S}$ and $30 \mathrm{~S}$ subfraction pools.

Ribosome concentration in all preparations was assayed spectrophotometrically at $260 \mathrm{~nm}$. using the extinction coefficientE $\mathrm{E}_{260 \mathrm{~mm}}^{1 \%}=145$ (Hill, Rossetti and Van Holde, 1969) in the equation:

$\underset{(\text { in grams per cent.) }}{\text { Concentration }}=\frac{\text { Dilution } \times A 260 \mathrm{~nm}}{145}$

\section{PRELIMINARY SKIN TESTING}

Four groups of guinea-pigs were sensitized as previously described using the following organisms:

Group I Six animals sensitized with $N$. gonorrhoeae which had been killed by heating at $100^{\circ} \mathrm{C}$. for $1 \mathrm{hr}$ (heatkilled), and used to make the IFA preparation as previously described.

Group II Six animals sensitized with $N$. gonorrhoeae which were killed by pouring the culture over ice and holding at $4^{\circ} \mathrm{C}$. for $24 \mathrm{hrs}$ (cold-killed). These were harvested and used to immunize the guinea-pigs as previously described.

Group III Six animals sensitized with heat-killed $N$. meningitidis.

Group IV Six animals sensitized with a heat-killed mixture of cultures of $N$. lactamicus, $N$. flavescens, and a Moraxella species.

Whole gonococcal cells and a gonococcal crude ribosome preparation from 7-day cultures of cold-killed $N$. gonorrhoeae were used to skin test four animals in each group. The preparations were diluted to $10 \cdot 0,5 \cdot 0,1 \cdot 0,0 \cdot 5$, and $0.25 \mu \mathrm{g} . / 0.1 \mathrm{ml}$. in saline or wash buffer respectively. The guinea-pigs were injected intradermally with $0.1 \mathrm{ml}$. of each of the cellular and ribosomal dilutions as well as saline and wash buffer controls. The reactions were observed at $24 \mathrm{hrs}$ after injection. Lesions were measured and volumes determined.

Skin test dose 50's $\left(\mathrm{STD}_{50}\right.$ ) were determined, using the method of Reed and Muench (1938) for determining 50 per cent. end-points. Six animals from each of the above groups were skin tested with dilutions of gonococcal crude ribosomes, $50 \mathrm{~S}$ ribosome fraction, $30 \mathrm{~S}$ ribosomal fraction, and sucrose controls 3 months after the final immunization. One boosting dose with cold-killed gonococcal cells was then given to the guinea-pigs in Group II to attempt to stimulate the reappearance of skin test reactivity. The skin test of this group was then repeated with the above antigens. 
Results of skin testing of sensitized guinea-pigs using gonococcal cells and crude ribosomes in animals sensitized to heat or cold-killed $N$. gonorrhoeae, heat-killed $N$. meningitidis, or heat-killed saprophytic Neisseria species indicate (Table I) that ribosomes from $N$. gonorrhoeae possess skin test reactivity in animals sensitized to homologous organisms and a specificity based on dose-size sensitivity different to that of skin test reactivity of animals sensitized to heterologous organisms. Saline controls were negative. The loss of skin test reactivity of guinea-pigs within 3 months after the final sensitizing injection is shown in Table II. Its reappearance after re-sensitization by a single booster dose of $200 \mu \mathrm{g}$. cold-killed gonococci is evident in Table III, which also shows further evidence that the intact gonococcal ribosome is of greater quantitative reactivity than are fractions containing its $50 \mathrm{~S}$ and $30 \mathrm{~S}$ subunits.

\section{Discussion}

The laboratory study of any disease requires the use of a suitable model system. The guinea-pig is not susceptible to gonococcal infection, but the animal can easily be immunologically sensitized; it was found to react to the various gonococcal antigens with a strong cell-mediated delayed hypersensitivity response.

The results indicate that the gonococcal crude ribosome is sensitive and specific for animals sensitized with homologous organisms. It was found that gonococcal crude ribosome preparations did not produce a positive reaction as defined above in animals sensitized to the closely related $N$. mening $i$ tidis (Kingsbury and others, 1969) or in animals sensitized with the more distantly-related saprophytic species. Although some degree of crossreactivity occurs, at least a five-fold difference in skin test antigen concentrations was observed. An interesting feature observed when the ribosomal subunits were being tested was the loss of sensitivity among the guinea-pigs after only 3 months. While the model system is indeed artificial, the decrease in sensitivity may be of clinical importance. It is possible that gonococcal antigens produce only a short period of sensitization, with a subsequent decrease in skin test reactivity. If this is true, it would be of extreme

TABLE I Delayed hypersensitivity reactions ${ }^{\star}$ elicited in guinea-pigs sensitized with cold-killed

$\mathrm{N}$. gonorrhoeae, heat-killed $\mathrm{N}$. gonorrhoeae, heat-killed $\mathrm{N}$. meningitidis, and heat-killed $\mathrm{N}$. lactamicus, $\mathrm{N}$. flavescens, and a Moraxella species, and skin tested with a mixture of gonococcal crude ribosomes and whole cells

\begin{tabular}{|c|c|c|c|c|c|c|c|}
\hline \multirow[t]{2}{*}{$S T D_{50}{ }^{b}(\mu g)}$. & \multirow[t]{2}{*}{ Sensitizing antigen } & \multirow[t]{2}{*}{ Skin test antigens } & \multicolumn{5}{|c|}{ Amount of antigen provoking reaction ( $\mu \mathrm{g})}$. \\
\hline & & & $10 \cdot 0$ & $5 \cdot 0$ & $1 \cdot 0$ & 0.5 & 0.25 \\
\hline $\begin{array}{l}3.00 \\
0.34\end{array}$ & $\begin{array}{l}\text { Heat-killed } \\
\text { N. gonorrhoeae }\end{array}$ & $\begin{array}{l}\text { Whole cells } \\
\text { Crude ribosomes }\end{array}$ & $\begin{array}{l}4 / 4^{\mathrm{a}} \\
4 / 4\end{array}$ & $\begin{array}{l}3 / 4 \\
4 / 4\end{array}$ & $\begin{array}{l}1 / 4 \\
4 / 4 \\
\end{array}$ & $\begin{array}{l}0 / 4 \\
4 / 4\end{array}$ & $\begin{array}{l}0 / 4 \\
1 / 4\end{array}$ \\
\hline $\begin{array}{l}4.53 \\
0.31\end{array}$ & $\begin{array}{l}\text { Cold-killed } \\
\text { N. gonorrhoeae }\end{array}$ & $\begin{array}{l}\text { Whole cells } \\
\text { Crude ribosomes }\end{array}$ & $\begin{array}{l}4 / 4 \\
4 / 4\end{array}$ & $\begin{array}{l}2 / 4 \\
4 / 4\end{array}$ & $\begin{array}{l}2 / 4 \\
3 / 4\end{array}$ & $\begin{array}{l}1 / 4 \\
3 / 4\end{array}$ & $\begin{array}{l}0 / 4 \\
2 / 4\end{array}$ \\
\hline $\begin{array}{l}5.00 \\
3 \cdot 68\end{array}$ & $\begin{array}{l}\text { Heat-killed } \\
\quad \text { N. meningitidis }\end{array}$ & $\begin{array}{l}\text { Whole cells } \\
\text { Crude ribosomes }\end{array}$ & $\begin{array}{l}4 / 4 \\
3 / 4\end{array}$ & $\begin{array}{l}2 / 4 \\
3 / 4\end{array}$ & $\begin{array}{l}0 / 4 \\
1 / 4\end{array}$ & $\begin{array}{l}0 / 4 \\
0 / 4\end{array}$ & $\begin{array}{l}0 / 4 \\
0 / 4\end{array}$ \\
\hline$\overline{1.92}$ & $\begin{array}{l}\text { Mixture of heat-killed } \\
N \text {. lactamicus, } N \text {. flavescens, } \\
\text { and Moraxella sp. }\end{array}$ & $\begin{array}{l}\text { Whole cells } \\
\text { Crude ribosomes }\end{array}$ & $\begin{array}{l}2 / 4 \\
4 / 4\end{array}$ & $\begin{array}{l}2 / 4 \\
3 / 4\end{array}$ & $\begin{array}{l}1 / 4 \\
2 / 4\end{array}$ & $\begin{array}{l}0 / 4 \\
0 / 4\end{array}$ & $\begin{array}{l}0 / 4 \\
0 / 4\end{array}$ \\
\hline
\end{tabular}

*24-hr reaction greater than $10 \times 10 \times 0.4 \mathrm{~mm}$. (15 mm. $\left.{ }^{3}\right)$

Numerator $=$ No. of animals positive. Denominator $=$ No. of animals tested

bSkin test dose 50

TABLE II Delayed hypersensitivity reactions ${ }^{\star}$ elicited in guinea-pigs 3 months after final sensitizing injection with cold-killed $\mathrm{N}$. gonorrhoeae and skin tested with gonococcal crude ribosomes, $50 S$ fraction, $30 S$ fraction, and sucrose

\begin{tabular}{|c|c|c|c|c|c|c|}
\hline \multirow[t]{2}{*}{$S T D_{b 0} \mathrm{~b}(\mu g)}$. & \multirow[t]{2}{*}{ Antigens used to skin test } & \multicolumn{5}{|c|}{ Amount of antigen provoking a delayed reaction $(\mu \mathrm{g})}$. \\
\hline & & $10 \cdot 0$ & $5 \cdot 0$ & 1.0 & 0.5 & 0.25 \\
\hline- & $\begin{array}{l}\text { Gonococcal } \\
\text { crude ribosomes } \\
\text { Gonococcal ribosomal }\end{array}$ & $2 / 6^{\mathrm{a}}$ & $2 / 6$ & $1 / 6$ & $0 / 6$ & $0 / 6$ \\
\hline - & $\begin{array}{l}50 S \text { fraction } \\
\text { Gonococcal ribosomal }\end{array}$ & $2 / 6$ & $2 / 6$ & $2 / 6$ & $0 / 6$ & $0 / 6$ \\
\hline - & $\begin{array}{l}30 S \text { fraction } \\
\text { Sucrose }\end{array}$ & $\begin{array}{l}2 / 6 \\
0 / 6\end{array}$ & $\begin{array}{l}1 / 6 \\
0 / 6\end{array}$ & $\begin{array}{l}1 / 6 \\
0 / 6\end{array}$ & $\begin{array}{l}0 / 6 \\
0 / 6\end{array}$ & $\begin{array}{l}0 / 6 \\
0 / 6\end{array}$ \\
\hline
\end{tabular}

*24-hr reaction greater than $10 \times 10 \times 0.4 \mathrm{~mm}$. $\left(15 \mathrm{~mm}{ }^{3}\right)$

Numerator-No. of animals positive. Denominator-No. of animals tested

bSkin test dose 50 
TABLE II I Delayed hypersensitivity reactions ${ }^{\star}$ elicited in guinea pigs given one boosting injection of cold-killed $\mathrm{N}$. gonorrhoeae three months after the final original sensitizing injection and skin testing with gonococcal crude ribosomes, $50 S$ fraction, $30 S$ fraction, and sucrose one week after boosting

\begin{tabular}{|c|c|c|c|c|c|c|}
\hline$S T D_{50} \mathrm{~b}(\mu g)$. & Antigens used to skin test & \multicolumn{5}{|c|}{ Amount of antigen provoking a delayed reaction ( $\mu \mathrm{g})}$. \\
\hline $0 \cdot 38$ & $\begin{array}{l}\text { Gonococcal } \\
\text { crude ribosomes } \\
\text { Gonococcal ribosomal }\end{array}$ & $6 / 6^{a}$ & $6 / 6$ & $6 / 6$ & $4 / 6$ & $2 / 6$ \\
\hline $0 \cdot 83$ & $\begin{array}{l}50 S \text { fraction } \\
\text { Gonococcal ribosomal }\end{array}$ & $6 / 6$ & $5 / 6$ & $4 / 6$ & $1 / 6$ & $0 / 6$ \\
\hline 0.68 & $\begin{array}{l}30 S \text { fraction } \\
\text { Sucrose }\end{array}$ & $\begin{array}{l}6 / 6 \\
0 / 6\end{array}$ & $\begin{array}{l}6 / 6 \\
0 / 6\end{array}$ & $\begin{array}{l}5 / 6 \\
0 / 6\end{array}$ & $\begin{array}{l}2 / 6 \\
0 / 6\end{array}$ & $\begin{array}{l}0 / 6 \\
0 / 6\end{array}$ \\
\hline
\end{tabular}

*24-hr reaction greater than $10 \times 10 \times 0.4 \mathrm{~mm} .\left(15 \mathrm{~mm} .^{3}\right)$

Numerator-No. of animals positive. Denominator-No. of animals tested

bSkin test dose 50

importance in any diagnostic test for gonorrhoea, where the possibility of repeated infection makes it difficult to differentiate between active infections and past infections which were successfully treated.

Skin testing of the sensitized animals demonstrated greater activity of intact, crude $70 \mathrm{~S}$ ribosomes than of fractions containing $50 \mathrm{~S}$ and $30 \mathrm{~S}$ ribosomal subunits. Further studies attempting further definition of the nature of gonococcal ribosomes as skin test antigens and as antigens in an in vitro correlate, the macrophage migration inhibition test, are described in the following paper (Judd and Koostra, 1976).

\section{References}

BaKeR, R. E., Hill, W. E., and Larson, C. L. (1973) Infect. and Immun., 8, 236

CASPER, W. A. (1941) Vener. Dis. Inform., 22, 119

CORBus, B. C., and CoRBUS, B. C., Jr. (1941) F. Amer. med. Ass., 116, 113

EditORIAL (1972) Brit. med. f., 1, 584

Esquenazi, V., and STREITFELD, M. (1973) Infect. and Immun., 8, 503

Grimble, A. S., and McIllmurray, M. B. (1973) Brit. f. vener. Dis., 49, 446

Handsfield, H. H., Lipman, T. O., Harnisch, J. P., Tronca, E., and Holmes, K. K. (1974) New Engl. f. Med., 290, 117

HerRold, R. D. (1922) f. Amer. med. Ass., 84, 361
Hill, W. E., Rossetti, G. P., and Van Holde, K. E. (1969) F. molec. Biol., 44, 263

- Thompson, J. D., and ANDEREgG, J. W. (1969) Ibid., 44, 89

Judd, R. C., and Koostra, W. L. (1976) Brit. f. vener. Dis., 52, 28

Kingsbury, D. T., Fanning, G. R., Johnson, K. E., and BRENNER, D. J. (1969) F. gen. Microbiol., 55, 201

KoHLER, H. (1931) Z. urol. Chir., 19, 54 (cf: f. Lab. clin. med., Abstr., 17, 497)

Kraus, S. J., Perkins, G. H., and Geller, R. C. (1970) Infect. and Immun., 2, 655

Lewin, R. (1973) New Scientist, 10 May, p. 355

LARSON, C. L., RIBI, E., BAKER, M. B., LIST, R., BAKER, R. E., and WICHT, W. (1966) Amer. Rev. resp. Dis., 94, 923

ReEd, L. J., and MuENCH, H. (1938) Amer. F. Hyg., 27, 443

Rossett, N. (1939) Yale f. biol. Med., 11, 345

SARKER, P. K., and SOM, S. (1969) Biochem. Biophys. Res. Comm., 37, 767

Schmale, J. D. (1970) Ann. intern. Med., 72, 593

Thayer, J. D., and Martin, J. E., Jr. (1966) Publ. Hlth Rep. 81, 559

Thompson, H. C. W., and SNYder, I. S. (1971) Infect. and Immun., 3, 16

Waksman, B. H., and Matoltsy, M. (1958) f. Immunol., 81, 235

Willcox, R. R. (1972) Brit. F. vener. Dis., 48, 504

Youmans, A. S., and Youmans, G. P. (1965) Proc. nat. Acad. Sci., 61, 122 